\title{
Basic Theory Of Islamic Education Management
}

\author{
Dausiri \\ UIN Walisongo Semarang \\ danusiri.29@gmail.com
}

\begin{abstract}
The purpose of this research is to find the principles science about the management of Islamic education. The realization of this principles are collection of various concepts, propositions, and theoretical theory (basic theory) on tahlili interpretation of a number of verses of the Qur'an or the syarah hadith tahlili to find the compound between the interpretation of verses or syarah hadiths with nomenclatures in concept, proposition, and theory of science of management of Islamic education. The result found 13 main principles of content and basic theory of Islamic education management namely : first, Islamic Education Planning is long-term planning until hereafter; Second, Manager responsibility that each action is asked accountability ; ThirdThe organizing principle is every functionary in an institution must be loyal to the top leader in the implementation of the task, etc.
\end{abstract}

Keywords:Islamic education Manajemen; principles; basic theory; responsibility; accountability

\begin{abstract}
Abstrak
Tujuan dari penelitian ini adalah untuk menemukan prinsip sains tentang manajemen pendidikan Islam. Realisasi prinsip-prinsip ini adalah kumpulan berbagai konsep, dalil, dan teori teoritis (teori dasar) tentang tafsir tahlili sejumlah ayat Al-Qur'an atau hadits syarah tahlili untuk menemukan senyawa antara tafsir ayat atau hadis syarah. dengan nomenklatur dalam konsep, proposisi, dan teori sains manajemen pendidikan Islam. Hasilnya menemukan 13 prinsip utama isi dan teori dasar manajemen pendidikan Islam yaitu: pertama, Perencanaan Pendidikan Islam adalah perencanaan jangka panjang sampai akhirat; Kedua, tanggung jawab Manajer bahwa setiap tindakan diminta pertanggungjawaban; Ketiga. Prinsip pengorganisasian adalah setiap pejabat dalam suatu institusi harus loyal kepada pemimpin puncak dalam pelaksanaan tugas, dll.
\end{abstract}

Kata kunci: Manajemen pendidikan Islam; prinsip; dasar teori; tanggung jawab; akuntabilitas 


\section{Introduction}

The purpose of this research is to find the figure of normative science about the management of Islamic education which the source is derived from the Qur'an and Sunnah Rasululillah. The realization of this figure is a collection of various concepts, propositions, and theoretical theory (grand theory) on tahlili interpretation of a number of verses of the Qur'an or the syarah hadith tahlili too. To determine which verses and hadiths, done by finding one or a number of words in management terms. Next, search the equivalent of the word in Arabic. After the Arabic equivalent is found, it is then used to search the verse or hadith in the Qur'an based on dictionaries made. For the Qur'anic verse uses "Mu'jam Mufahras" by Ahmad Fuad 'Abd al-Baqi and for the hadith uses the 2009 lidwa library which contains Kutub alHadis at-Tis'ah. Then, do the tafsir (interpretation) of the intended Qur'an surah and syarah hadith tahlili.

After the interpretation results obtained, next step is to find the compound between the interpretation of verses or syarah hadiths with nomenclatures in concept, proposition, and theory of science of management of Islamic education. The compounding principle is similar to qiyasadna, that is, finding a conclusion based on a higher-level proposition (major and comprehensive). It can be exemplified, when it comes to the interpretation of the verse 'lillāhi mulk as-samāwāti wa al ardl' with 'Allah is the king of the kingdom of the heavens and the earth', it can be formulated the basic theory and normative management that "rector is the most powerful in universities (universities or institutes), the dean is the most powerful person in the faculty, and the director of the study program is the profile of the most powerful person in the department.

The research model uses the procedure: (1) collecting Qur'anic verses that can be associated as verses of Islamic education management, (2) In collecting paragraphs starting from the key words that are used in the repertoire of Islamic management education in the introduction of Indonesian, copied into Arabic, then used to search the verse by utilizing the mufahras books for the Qur'an, (3) translating the verses into Indonesian by using digital Qur'an, (4) explaining the words deemed necessary to clarify concepts relevant to the element of 
Islamic education management, interpreting the principles of each verse to obtain the main content, then formulating the basic theory of the main content of the verse. Technique taken is to state the composition between the main content in the elements of science, concepts and theories, management of Islamic education.

The formulation of basic theory in this paper is divided into 14 categories according to the subject in the lecture meetings (14 meetings). The accumulation of the 14 categories of basic theory formulation of Islamic education management is expressed as the figure of the basic theories of Islamic education management.

\section{Findings}

The researcher found 13 main principles of content and basic theory of Islamic education management, namely:

1. Islamic Education Planning

a. The Qur'an Surah ad-Duha/93: 4 and Surah al-'Adiyat/100: 9-11 contain the basic doctrine that (1) The Hereafter is better than now, that is life and this world life. (2) In order to have good life in the hereafter, it must be well prepared since now still alive in this world. From the basic contents of this paragraph can be formulated basic theory: (1) Islamic education management performance must be maximally successful. (2) Therefore, in carrying out Islamic education management must depart from a careful planning, detailed, gradual, and a good time-schedulling.

b. The Qur'an of Surah al-Mu'minûn/23: 12-14 and alInsyiqaq/84:19 contain the main lessons that both creation and the fact of life are stratified from such a humble being to the level of the most perfect being, from weak to strong and able to do many things. Basic theory that can be formulated from the main content of these two verses is: the realization of planning must determine the sequence of easy start and ended with the difficult one, ranging from simple to complex, ranging from mild to severe, ranging from short to long term, and start from the most fundamental such as vision-mission-goal of education management to something that is enriching. 
2. Manager and It's Responsibility

a. The Qur'an of Surah at-Takastsur/102: 8 and al-'Adiyat/100: 9-11 contain the basic lessons, namely: (1) all human actions in the world will be revealed by God, (2) furthermore, each action is asked accountability. Basic theory that can be formulated from the two main content of the verses are: (1) Anyone who is involved in educational institutions, from the bottom staff to the top leader must be accountable for all their performances in detail, measurable, and observed in accordance with their job description to their mandate giver or employer. (2) The accountability is not merely the employment relationship in his position, but also the accountability in life after death because the institution uses the basis of Islam implementation.

b. The Qur'an of Surah as-Sajdah/32: 23 and Surah al-A'raf/7: 3 contain the basic of lessons those are: (1) The leader must give guidance which comes from God, including from the Messenger of Allah. (2) Before convincing others of the truth of the guidance contents, he himself must be convinced first so that the subordinate will be steady in carrying out his leader's guidance. (3) The stability will be tested after trials in the execution of the instructions. He remains patient, firm, and resilient in carrying out the instructions because he believes what he does is right.

Basic theories that can be formulated from the main content of this paragraph are: (1) Every functionary from top leaders, managers to the lowest staff position in the structure must work in accordance with the established planning, (2) Working based on the plan is the responsibility or trust they have to carry out. (3) In such positions shall not work using other guidelines or plans. The result will be an overall detriment in the institution because anyone involved in it is part of a system that each cooperates in accordance with its responsibility in realizing its intended purpose.

3. The organizing

a. The Qur'an of Surah al-Fatihah/1: 5 contains the basic lessons: (1) Only to God, men worships. (2) Only to God, men asks for help. From the main content of this paragraph 
can be formulated basic theory that (1) Every functionary in an institution must be loyal to the top leader in the implementation of the task. (2) If each functionary has difficulty in performing the task, they can propose to the top leader the improvement of performance skills, such as by training, work meeting, and workshop.

b. The Qur'an of Surat al-Baqarah/2: 45 contains the basic doctrine, those are: (1) Muslims should only ask Allah for help through patience and prayer. (2) God's warning to man that only the khusyu' in prayer alone plead for help to God in overcoming the difficulties of his life. From the two main content of this paragraph can be formulated the following basic theories: (1) For each functional in an institution must be patient and earnest in following performance improvement program, for example training, workshop, work meeting, and comparative study; (2) Only those who really follow the performance improvement program can improve the performance competence.

c. The Qur'an of Surah Ali Imran/3: 159 contains the basic lessons: (1) Mu'asyarah (communicating) with others must be based on courteous and gentle manner and speech. (2) If you mu'asyarah with a hard attitude then the person who invited mu'asyarah will leave. (3) The command or at least the appeal for mu'asyir (khathib) to apologize for the mistakes of mu'asyarah 'alaih (mukhathab) in doing mu'asyarah. (4) The command or at least the call to pray for forgiveness to Allah of the mistake of mu'asyarah 'alaih in doing mu'asyarah. (5) Among Muslims or more widely among human beings are suggested to do discussion (deliberation) in solving the problems that arise amongst. (6) Deliberation must reach the level of generating collective agreements. (7) The agreement had been reached must be a mutual commitment. (8) The commitment must be based on the power of Allah, it means it has ilahiyyah value.

From the eight basic contents of this paragraph can be formulated the following basic theories: (1) The existence of the function of organizing all elements of both natural resources and human resources is absolute. (2) Human 
resources include top leaders such as leaders and managers to the lowest level and rank of staff in the structure. (3) Each functionary must work based on his/her task and function. (4) Each functionary must be able to cooperate to each other in the related areas. (5) The greatest responsibility lies in the top leader hands, because he must be able to organize his employees effectively and efficiently. (6) Problem occur in carrying out the management should be solved together by deliberation to reach an agreement. (7) To be effective in solving the problem must be in a good human relations atmosphere amongst the persons. (8) A higher manager or officer or any functionary in a management shall be able to give apologize to the proven wrongdoers who have agreed upon agreement. Furthermore, he/she even shall ask forgiveness to Allah for the mistake that the wrongdoers have made. (9) If the agreement has been reached in the deliberation, it should be upgraded to be a mutual commitment, then the management activities and the whole program are based on the joint commitment. (10) Commitment must be transcended to Allah, it means committing and carrying out commitments are based solely on Allah, certainly to gain His approval.

4. Coordination Function

a. The Qur'an of Surah Asy-Syuraa/42: 38 contains of basic lessons such as: (1) There are those who obey God's commandments. (2) Their form of obedience to God is to establish shalat (prayer). (3) If there is a problem between them, deliberation is the way to go. (4) They spend some of the sustenance which Allah bestows upon them. From the main content of this paragraph can be formulated basic theories: (1) In an institutional unit must create a deliberation atmosphere among all functionaries in carrying out the organization activities. (2) Deliberation covers draft planning, activity realization, and monev (monitoring and evaluation). (3) Deliberation in the technical sense may be done in the form of seminars, workshops, or work meetings (Raker). (4) The deliberations may be limited by certain officials, may involve all existing employees, depending on the circumstances and conditions. 
b. The Qur'an of Maryam/19: 29 contains the basic lessons as follows: (1) Maryam surroundings accused her of committing adultery as 'Isa bin Maryam was born without a father. (2) Against the accusation, Maryam refers to her son to answer (the accusation). (3) Isa bin Maryam was still a baby at that time. (4) Apparently, the baby Isa bin Maryam can speak. (5) The answer to the accusation of adultery is astonishing, that he claimed to be a prophet and was given a Kitab by God.1

From the main content of this paragraph can be formulated basic theory, as follows: (1) In an organizational unit or institution must create a deliberation atmosphere among all functionaries in carrying out their organizational life. (2). Deliberation covers since planning draft, activity realization, until monev (monitoring and evaluation). (3) All members, from the manager to the lowest staff, should be treated the same as their respective functions, so no one is underestimated. (4) If there are difficulties in carrying out the obligations, these difficulties must be solved together (coordinated) fairly, transparently and objectively so that no parties will be harmed. (5) The activity continues, while the $u d z u r^{\prime}$ one is not depressed. (6) The atmosphere within the institution should be comfortable for each functionary in working based on his/her duty and function. (7) The mental foundation that must be built in performing this obligation is taqwa to Allah SWT.

c. The Qur'an of Surat al-Baqarah/2: 233 contains the main learnings as follows: (1) There is cooperation between husband and wife, that is in fostering the household. (2) The wife suckles her child for two years (if she wants) and is allowed by her husband. (3) The husband earns a living to support his family, in this case the child and his mother (the

1 Although it appears that Isa bin Maryam's answer is not contextual with his accusations, it is a very strong proof that Mary did not commit adultery as her people claim because the baby can speak, and even preach to the truth, that he is the messenger of God by showing evidence the His Kitab. 
wife). (4) The living that is used to support the family has a quality of ma'ruf. The original meaning of the word "ma'rûf" is 'idraku syai" bi tafakkutri watadbīi liatsarihiz (finds something by way of thinking and learning the traces of it. For example, it is known that the one who is shouted offended or angry, and the anger behaves in antipathy to the barker. Then the barker stops snapping again). (5) Obligations of each (wife or husband), should not be burdened beyond capability. (6) That is why if the wife wants to wean her child before two years for any important reason, for health, then the husband should allow it. (7) For the sake of the child's health, the baby may be exposed to others on the basis of deliberations between husband and wife. (8) All life relationships between husband and wife must be based on taqwa-llāh (9) That Allah knows every phenomenon in the life of husband and wife. 3

From the main content of this verse can be formulated basic theory: (1) All functionaries, from the manager to the lowest staff should be treated the same. (2) If in performing the task there are difficulties, then this difficulty must be solved together (coordinated) well so that no parties are harmed. (3) Management activities continue, while the $u d z u r^{\prime}$ one is not depressed. (4) The atmosphere within the institution should be comfortable for each functionary in working based on his/ her duty and function. (5) The mental foundation that must be built in performing this obligation is taqwa to Allah SWT. (6) Performance accountability is not only accountable to humanity, but also to God Almighty, in the last day.

2 Ar-Raghib al-Ashfahāni, Mufradāt Alfādl al-Qur'ān, (Damsiq-Beirut: Dar al-Qalam-dar as-Sāmiyyah), 1992 M/1412 H, h. 560.

3 Practically God knows if a husband or wife is doing good or doing bad for his/her family. God will reply in accordance with the deeds they do. 


\section{Employee Salaries4}

a. The Qur'an of Surah al-Baqarah/2: 62 contains the basic lessons: (1) The believers may consist of: a) People who have previously believed in Islam, such as the muhajirin, b) Persons previously derived from Christian, c) A person who was a Jewish before, d) A person was a worshiper of star, (2) The believer object of faith is God and the last day. (3) The true intentions of faith are manifested in the form of shalih deeds (good deeds).5 (4) Those who believe in Islam will get their reward from their Lord. (5) The person who gets the reward will not get any worries in the hereafter. (6) The person who gets the reward from God will not trouble in the Hereafter. From the main content of this paragraph can be formulated basic theories: (1) Employees of an institution can come from different backgrounds. (2) After becoming member in the institution must have the same views, among others serve the institution how to be good. (3) The similarity of views of all functionaries is manifested in good performance. (4) All functionaries shall be entitled to receive salary for their performance. (5) All functionaries must create a comfortable atmosphere at work and free of a sense of worries, of course includes post-employment status that is retirement. All the elements in the institution together work on a comfortable atmosphere.

b. The Qur'an of Surah Muhammad/47: 36 contains the basic learnings: (1) The life of the world is just a game. (2) The

4 Mentioned the word ajrun and various i'rab and his idhafah in the Qur'an 105 times. See: Ahmad Fuad 'Abd al-Baqi, Mu'jam Mufahras li Alfādz al-Qur'an al-Karīm, (Indonesian: Maktabah Dahlan, [t.th]), p. 17-18. This suggests that the Qur'an forbids anyone to exploit others, or forbids slavery. No matter how small a person asks for services to others, a commensurate fee must be paid to him.

5 The word 'shalih' is opposed to 'fasid' or 'syayyiah'. The word 'fasid' is interpreted against the will of God. Thus what is meant by the pronounciation of 'righteous' according to the will of God. See: al-Ashfahani, op cit., P. 489490. Zinah means doing the facade because God forbid it, 'wala taqrabû azzina $\bar{a}$, while giving a pack of rice to fellow human being who is starving is' righteous' because it is recommended by God. In his word 'ta'āwanû ala albirri. . 
life of the world is only jokes. (3) If men believe and fear Allah, He will reward them. (4) God does not ask for human property. From the main content of this paragraph can be formulated basic theories: (1) Salary is given only to employees who work on the basis of his contract work. (2) The right of salary for an employee shall not be deducted by the employer for any reason.

c. The Qur'an of Surah an-Nisa'/4: 24 contains the main lessons: (1) Husbands are obliged to give nafaqah to his wife. (2) The reason of the husband's duty to the wife is that he enjoys her, in the sense of copulating his wife. From the main content of this paragraph can be formulated the following basic theories: (1) Every employer, director, etc, shall give salaries to employees. (2) The reason for the obligation to pay salaries to employees is their performance in the employer's own institution.

\section{Management of Learning Curriculum}

a. The Qur'an of Surat al-Fatihah contains the main lessons: (1) From basmalah can be concluded as the teachings of Tawheed rububiyyah, believes that only Allah is the care of the universe with affection. (2) From hamdalah can be concluded as the teachings of Tawheed uluhiyyah, that is, Allah alone is entitled to be praised and worshiped. (3) From the third verse it can be concluded that God still grants affection to all beings (tauhid rububiyyah) even though his servants are disobedient to him. (4) From the fourth verse it can be concluded that God is the sole ruler and judge on the day of vengeance. God will do justice to those who do good with the reward of heaven, and hell to who disobey His command. (5) From the fifth paragraph can be concluded that people who believe in tauhid uluhiyyah and rububiyyah just devote themselves and ask for help to God. (6) From the sixth verse it can be concluded that the content of the request for help is to be shown to the righteous path by God. (7) From verse seven it can be concluded that the straight path is ad-din al-Islām itself. At once begged to be kept away from the way of life of those who were wrathful of God, the Jews, and the way of life of the heretics, namely Christians. 
From the seven main content of these verses can be formulated basic theory as follows: (1) The basic materials that needs to be managed in Islamic education management study include: aqidah, namely tauhid rububiyyah belief, tauhid uluhiyyah, tauhid asthma wa sifat, (life after death), the law of God of justice, worship, al-akhlaq al-karimah, shirāthal al-mustaqīm) and away from al-akhlāq almadhmûmah (shirāthal a-maghdlûb and shirāth adldlāllûn). (2) The educational curriculum in the form of learning materials is formulated by education providers, as God shows the paths of truth. (3) During the period and stages of learning realization, starting from PIAUD to S3 program still must istikomah and dynamically anticipate the development of the time so that the educational material remains relevant, not out of date. (4) In carrying out the established curriculum it should be more intensively implemented as well as possible. This is the picture of tawakkal for muwakkilûn. (5) A curriculum change is possible if the result of the change leads to a better outcome of the learner than before the curriculum changes. (6) The implementation of the new curriculum, in the near future, is of course not yet socialized to the competent thoroughly. Therefore, assistance in the implementation of this activity is very necessary for the new curriculum to run effectively. (7) Educational personnel, both teacher and educational staf must keep doing their best, based on professionalism, while avoiding any form of misappropriation.

b. The Qur'an of Surah Ibrahim/14:12 contains the basic lessons: (1) The believers only trust to God as an expression of gratitude to Him for showing the way to them, (2) Believers are patient whenever there is a disturbance in putting up with Allah because of the magnitude gratitude to Him, (3) The intensity of the burden of the believing believers has been upheld in true surrender. From these three basic learnings can be formulated basic theories: (1) Good educators base their work on competence and professionalism, (2) Educators must be patient and tenacious when encountering interference. Disorders must be handled properly so that the education process goes 
normal again, (3) The educator must update himself continuously regarding his competence and professionalism.

c. The Qur'an of Surat al-'Ankabut/9: 69 contains the basic learnings: (1) The man who strives to seek Allah's approval for Allah shows the way to Him, (2) One of the forms of jihad towards Allah's pleasure is the person who does good (al -muhsin), (3) al-Muhsin will be accompanied by God as long as he does good. From these three main learnings can be formulated basic theories as follows: (1) Educators who always base on the competence and professionalism will gain ease in carrying out their duties, (2) Competent educators, professional, loyal, and achievers will receive an award from the authorities.

\section{Human Resources}

a. The Qur'an of Surat al-'alaq/96: 1-5 contains basic teachings:

(1) Allah commands Muhammad and his followers, ie Muslims, to read. (2) In the execution of reading must be in the name of God, that is Allah Almighty Himself. (3) God is the creator other than Himself, that is the universe, including the content and the laws that are in it, namely sunnatullah. (4) The object to read is God's creation itself. (5) God created man comes from a clot of blood. (6) Allah repeated the command of reading to Muhammad saw and all his people. (7) Allah is All-Merciful. (8) God teaches human beings with intermediaries kalam. (9) Teaching material is anything that is not yet known by man.

From the main content of these verses can be formulated basic theories: (1) Human resources in learning include learners and learners. (2) Learning materials should be clear, in a focused sense. (3) Learners are obedient to the rules applicable in it. Learners must be obedient and respectful to the lesson. (4) The lesson instructor should provide teaching materials in accordance with the prescribed curriculum.

b. The Qur'an of Surah ar-Rahman/55; 1-4 contain the main lessons: (1) God is most generous. (2) Allah taught the Qur'an to man. (3) God is the creator of man. (4) God taught man. (5) The teaching material is the way of speaking. From 
the main content of this paragraph can be formulated basic theories: (1) The main task of educators is to educate learners. (2) Educators should be affectionate towards learners. (3) It is the educator who is responsible for making the learners have the skills in accordance with the purpose of education

c. The Qur'an of Surah al-Baqarah/2: 30-33 affirms the main lessons as follows: (1) Allah says to the angels that He will create a caliph in the earth. (2) The angels ask God. (3) The question is why to create the Caliph. (4) The angel's question is actually a protest because they predict that the caliph will shed blood. (5) To reinforce his protest, Angels claim that they are the ones who are accustomed to exalt Allah. (6) God does not answer the question of angels. (7) God reveals that He knows what the Angel does not know. (8) God teaches Adam, the human species, the various names, things. (9) God told the Angel to mention what God had taught Adam. (10) Angels declare themselves incapable of carrying out orders. (11) Angels only know something that God has taught them. (12) The angel declares that Allah is All-Knowing. (13) Angels claim that Allah is Wise. (14) God commands Adam to mention names. (15) Adam executes the commandment of God, which is to mention names, in the presence of the Angel. (16) God declares in the presence of the Angel that He knows the wonder of the heavens and the earth. (17) God knows the inner content of the Angel. (18) God also knows the inner content hidden by the Angel. (19) The style of God's language in declaring His knowledge before the Angel is burhaniyyah (showing proof).

From the main content of these verses can be formulated basic theory, namely: (1) In learning activities there must be educators and students. (2) In the learning process must occur dialogical atmosphere (3) Educators must really master the learning materials. (4) Educators must master the ongoing learning forum. (5) Learners should be positive, ie adjust to the rules of learning, during the learning process takes place. (6) Educators should make feedback, ex: post test and resume teaching materials. (7) 
Educators must know the level of absorption of learning materials by the learners. (8) Learners show their competence after following the learning process. (9) Students must be willing to show their ability to master educational materials when appointed by educators. (10) Students who have not mastered the learning materials should be respectful to educators and to learners who have mastered the learning materials. (11) Against learners who have not mastered the learning materials, educators should keep them with affection.

\section{Manager has Principle to ease}

a. The Qur'an of Surat al-Baqarah/2: 201-202 contains the basic lessons: (1) Some people pray "Rabbanā ātināfi addunyā hasanah wafi al-ākhirati hasanah waqinā 'adzābannār" (2) Prayer continued with concrete efforts. (3) The combination of prayer and effort will produce what is cultivated. (4) God's count is very fast. From the main content of this paragraph can be formulated basic theory, among others: (1) All elements of functionaries in an institution must pray in starting work. (2) The content of prayer should be about success and blessing. (3) Completed prayer followed by work in accordance with procedures. (3) Pray and work for an opportunity to obtain maximum results.

b. The Quran of Surah Ali Imran/3:19 contains basic lessons such as: (1) Religion (the belief) is only Islam. (2) The ahli Kitab feel envious to the truth of Islam. (3) God very quickly calculated against the malice of the Ahli Kitab. From the three main contents of this paragraph can be formulated basic theory, as follows: (1) Each element in an organizational unit must be sure that the organization that he merged into it is good and right. (2) When a person has joined the organizational unit, he or she must be loyal to it, and should not tarnish it. (3) If he tarnished the organization, the bad risks would come soon.

c. The Qur'an of Surat al-Baqarah/2: 212 contains basic teachings, among others: (1) The life of the world for the unbelievers. (2) Unbelievers despise the believer. (3) Actually, the cautious person is more noble than the kafir 
tomorrow on the day of kiyamat. (4) God gives sustenance to the one whom He wills without limit. From the main content of this paragraph can be formulated basic theory: (1) Working at will alone in an organizational unit is fun for functionaries who do not have commitment to the institution in which he works. (2) Precisely, the disciplinary functionaries consider lowly for functionaries who work sincerely. (3) The functionary who works earnestly who will get good from the results of his work. (4) One of the favorites received is the variety of gifts from his superiors.

\section{Show Goodness To Others}

a. The Qur'an of Surat al-Kahf/18: 110 contains the basic lessons: (1) The Prophet Muhammad was a human being. (2) The difference with another human being, he was given revelation by God. (3) The contents of revelation mention that God is One. (3) Whoever hopes to meet God, he has to do good deeds. (4) Besides, he is forbidden to associate Allah with anything and anyone. From the main content of this paragraph can be formulated basic theories: (1) Top leader is actually the same with the lowest staff though. (2) The difference between the top leader and the others, he who has the authority to convey messages, orders, reprimands to all his employees. (3) Every element in the institution must establish good communication to its leader. (4) Every element in the institution is prohibited to be ambiguous, including following the actual command not the leader.

b. The Qur'an of Surah al-Hajj/22: 38 contains the basic learnings: (1) God sided with the believers. (2) God does not like traitors, among others, denying favors. From these two main teachings can be formulated basic theory, that (1) Top leaders always side with every functionary who work on the basis of guidelines that have been set. (2) Top leaders certainly do not like functionaries who trait his work.

c. The Qur'an of Surah al-Baqarah/2: 55 contains the basic lessons: (1) The prophet Moses followers did not want to believe, but they sent diplomacy if he could see God they would do. (2) After challenging Moses, they were struck by lightning. (3) The Prophet Moses saw the stubborn people 
struck by lightning. From the content of these basic teachings can be formulated basic theories: (1) functionariest of an institution that does not have commitment to the institution, will just looking for justification for the discipline. (2) The disciplinary functionary typology will certainly receive a very lethal consequence, i.e. very heavy sanctions of being fired. (3) Other functionaries will surely witness the granting of severe sanctions as learning, in order not to follow the disciplinary attitude.

10. Leader Betrayal

a. The Qur'an of Surah al-Baqarah/2: 35-36 contains basic lessons: (1) God commands Adam and his wife to occupy heaven. (2) God gives facilities in heaven, among others, unlimited food. (3) Adam and his wife were forbidden by Allah to approach the tree, khuldi. (4) If Adam and his wife violate this prohibition, surely he tortures himself. From the main content of this doctrine can be formulated basic theories: (1) Each functionary in an institution must be given adequate facilities for kelancara carry out their duties. (2) Not only facilities to work for functionaries, but also stimuli that can increase work arousal. (3) Signs that should not be performed for functionaries should be clear and firmly implemented. (4) If the functionary violates the rules of the institution, he is just as prepared to accept a bad risk for him.

b. The Qur'an of Surah at-Taubah/9: 100-102 contains the main lessons as follows: (1) The (large) social group called Muhajirin. The characteristic of this group is that Allah is pleased with them and they are also pleased with Allah. (2) A (large) social group called Ansar. The characteristic of this group is like the social group of Muhajirin, that Allah is pleased with them and they are pleased with Allah. (3) Small groups affiliated with both the Muhajirin and the Ansar groups, that is, each group, is pleased with Allah and Allah is pleased with them. (4) The social group of the Muhajirin, the social group of Ansar, and other groups affiliated with these two great groups are promised by God the great fortune of heaven. (5) A'rab (small) social groups. 
They are close in contact with the Muhajirin and Ansar groups, where the leaders of these two great groups are the Messenger of Allah. Technically A'rab is called a munafiqun. (6) Small, native urban groups called maraddun-nifāq, which practically mean too much in hypocrisy. (7) The behavior of nifaq (over hypocrite) of this group is not known by the Prophet alone. (8) The behavior of nifaq (over hypocrite) is found after being investigated by the people, of course the servants of the Messenger of Allah both of the Muhajirin and the Ansar or those affiliated with them. (9) Due to the behavior of nifaq (over hypocrite) will get the punishment from Allah twice (marrataini) then added a very painful eternal punishment. (10) Other social groups are characterized by confusing between good deeds and bad deeds. This confusion between good deeds and bad deeds are done in purpose. (11) To the social group that confuses between good deeds and bad deeds is expected to return only good deeds and leave the bad on the basis of understanding and consciousness.

From some basic content of this paragraph can be formulated basic theory, as follows: (1) Some personal functionaries work in accordance with the field of duty. (2) The mental base in performing the task given is happiness, in the sense of enjoying his work. (3) The person who works on the basis of loving his or her work will be favored by the assignor and vice versa. (4) Other variants of worker, there are personal who work fraudulently, aka dishonest. (5) Fraud personal or employee (of the fourth variants) above is difficult to know by superiors, peers, or lower level employees. (6) Only by joint tracking in earnest, their cheating, the 4th employee variant above, can be dismantled. (7) The fourth employee variants threats are sanctions. If the fraud is too detrimental to the institution, it may be punished severely in accordance with his/her fraud. (8) Other variant of employee is person who work haphazardly, outrageous or technically do not have professionalism. (9) This type of person number eight above, in time will be crushed disastrous havoc, may be humiliated, dismissed from duty or position. After being 
fired he can become miserable, then his family life can be messy, and may be suicidal because of despair. Finally in the hereafter, of course, including people who will get a very painful penalty. (10) The last variant is the personal who work mixing between right and wrong. Typically, the typology of this variant is very commercial in return. If there is an honorarium, he/she works. If his/her honorarium is large, he works hard. If it is a small one, he works arbitrarily, in Javanese said as leda-lede (not serious/ not professional). If there is no honorarium only excuses are offered, while the work is zero. (11) This 10th varian employee must be nurtured continuously until he/ she realizes that his/her works in the institution is part of worship or performs the mandate he or she has declared when confirmed to be an employee, inaugurated to occupy certain position or duty.

\section{Student Affairs Management}

a The Qur'an of Surah al-Baqarah/2: 283 contains the main lessons: (1) Doing business in a state of travelling, when doing transaction in a non-cash manner, the debtors must give a guarantee. (2) The existence of the guarantee deposited by the debtor to the creditor is necessary so that the lender is not deceived (3) If each party, the debtor or lender is trustworthy, the existence of the guarantee may be unnecessary. (4) The debtor party is ordered to remain taqwa to Allah in the sense of keeping trust from the lender. (5) The witnesses to the debt transaction must be honest, tell the actual event when there is a dispute between the debtor and the lender. (6) If the witness is dishonest in his testimony, he receives an inner sin. It means that formally and outwardly he is right, but inwardly he is cheating. (7) Cheating witnesses are known by God. in the sense that there is a threat of torture in later days.

From this main content can be formulated basic theory, as follows: (1) Provision of any task to the functionaries of Islamic education management institutions there should be legal evidence, eg: letter of assignment, decree, etc. (2) After completion of the task there must be a written report to the assignor. (3) The assignor shall provide evidence that 
the task has been carried out, whether the completion is complete or any particular notes. (4) Evidence of acknowledgment of the duties issued by the assignor may be in the form of an official report, a letter of appreciation, a certificate, or alike. (5) Official operating standard procedures in the assignment and execution of duties shall be equally honored and executed. (6) If either party or both violates SOP (Standard of Operating Procedures), it will be disastrous for both parties and the institution.

b Al Quran Surah al-Fāl/8: 27 contains the following main lessons: (1) Prohibition for the believers to betray Allah. (2) The prohibition for the believers to betray Rasulullah. (3) The prohibition for the believers to betray the trust they have embraced. (4) The rules of all these restrictions are essentially known by the believers.

From the content of this basic doctrine can be formulated the following basic theories: (1) Prohibition for every work implementer (functionaries) in an institution, including the study program of Islamic education management, to betray Allah and Rasulullah because both are mandate giver on the basis of islamiyyah faith. (2) Prohibition of every worker (functionary) within an institution, including the department of management of Islamic education, to betray his/her duties or job description established by employers, rectors or representative. Since basically, duty or job description is a trust for him.

c The Qur'an Surah al-Mu'minûn/23: 8 contains the basic lessons: (1) Some ikhlash people maintain the mandate that is borne to him. (2) The person who can keep the trust also holds its promise. From the main lessons of this paragraph can be formulated basic theory that (1) Stakeholder or staff of any kind are only deserve for people who are competent, professional in their field. (2) Occupying a position is understood as an amanah (mandate) to be carried out according to promise when spoken during his/her inauguration.

12. Monitoring and Evaluation

a The Qur'an Surah al-'Adiyât/100: 11 contains the basic lesson that Allah knows the state of man on the day of 
kiyamat. From the main content of this paragraph can be formulated basic theory that all elements and work results of each functionary of an institution, inclusive to study program of management of Islamic education, from the highest officials to the lowest level officials and all staff, must be audited objectively according to their field of work, duty and functions. The results of the audit should be shared as the way it is (should be shared).

b The Qur'an Surah at-Takâtsur/102: 8 contains the basic doctrine, that whatever has been a pleasure to man must be held accountable audit by God. From this basic content can be formulated basic theory that all elements and work of each functionary of an institution, inclusive to study program of management of Islamic education, from the highest officials to the lowest level officials and all staff must be audited objectively according to their field of work, duties and functions.

c The Qur'an Surah al-Qari'ah/101: 6-9 contain the basic lessons: (1) In the Hereafter every human being is held accountable by God to his/her deeds in the world. (2) Every action is weighted. (3) The weighting ranges of the smallest and lightest deeds, the dzarrah, to the greatest and the heaviest. (4) Anyone who, after being weighed between good deeds and bad deeds, weighs his/her good deeds, then he/she will be saved. (5) Anyone who, after being weighed between good deeds and bad deeds, weighs heavier his/her bad one, then he/she will be damned.

From the main content of this paragraph can be formulated the following basic theories: (1) All employees of institutions of Islamic education management courses, ranging from the highest officials to the lowest officials, including all types of staff, will receive the results of performance audits in the form of assessment from employers. The weighted value starts from the worst failure rate to perfect success. (2) If a functionary accepts an assessment of work in a successful category, he will feel happy or proud, to be proud of by his family at home, his colleagues in which he works, as well as by employers. (3) If a functionary accepts an appraisal of a work in a failed 
category, he or she will be disappointed, to be bankrupt and given sanction by the employer. (4) The size or severity of a sanction shall be objective or fair so as to avoid harming the functionaries being audited, no 'circumcision' nor mark up of records of audit results.

\section{Financial Management}

a The Qur'an Surah al-Baqarah/2:16 contains the main lessons:

(1) The hypocrites buy faith with digression. (2) The hypothetical or dishonest trading model will only result in a loss. (3) The hypothetical or dishonest trading model will not get a guidance from Allah.

From the main content of this doctrine can be formulated basic theory, as follows: (1) There is a dishonest financial management model. (2) Managing dishonest finances harms both themselves and the institutions in which they work, for example in Islamic education management department. (3) Models of dishonest finance management will be far from the correct rules of financial management.

b The Quran Surah Luqman/31: 16 contains the main lessons: (1) Luqman gives instruction to his son about goodness. (2) The content of the lesson is any virtues of the slightest kindness will be known by Allah. (3) God has the subtle attribute, that of knowing everything. (4) The intention is that even the smallest deeds of merit will be rewarded by Allah.

From the main content of this paragraph can be formulated basic theory, as follows: (1) Top leaders in an institution, eg. Islamic education management study program, provide rules or guidelines of financial management for financial managers. (2) Top leaders instruct financial managers to work in accordance with existing guidelines. (3) Any implementation of the work in managing the finances should always be evaluated so that the slightest error can be known to improve performance. (4) To be able to know the faulty performance of financial management, personnel should be facilitated by sensitive and accurate device, such as high level IT [information technology]. 


\section{Conclusions}

The accumulation of basic theory from number one to number 13 can be compressed as a conclusion to be a basic theory of Islamic Education Management of Quranic-prophetic on Islamic Education Management Department of Faculty of Tarbiyah and Educational Sciences of Walisongo Islamic State University of Semarang. Furthermore, this set of theories is placed as a branch of a science, 6 named as the science of quranicprophetic education management. The theory of compression theory refers to the theory of science, the systematic collection of concepts, propositions, and theories. Strictly, science is a systemic collection of theories, 7 or regularity of data. 8

\section{References}

al-Qur'ān al-Karīm.

Al Quran Digital versi 2.1, 2004

'Abd al-Baqi, Ahmad Fuad, al-Mu'jam al-Mufahras li Alfādz alQur'ān al-Karìm. Indonesia: Maktabah Dahlah, [t.th]. al-Ashfahāni,ar-Raghib, Mufradāt Alfādl al-Qur'ān, DamsiqBeirut: Dar al-Qalam-dar as- Sāmiyyah), 1992 M/1412 $\mathrm{H}$

Danusirti, Nadwa, vol. 10, 2 Oktober 2016.

Kemeny, John, A Philosopher looks at Science, New York: Van Nostrand Reinhold, 1981.

Lachman, Sheldon J., The Foundations of Science, New York: Vantage Press, 1989.

A.Kadir, Ilmu Islam Terapan, Yogyakarta: Pustaka Pelajar, 2003. Popper, Karl R., Realism and The Aim of Science, Totowa: Rowman and Littlefield, 1983

Russel, Bertrand, Human Knowledge, Its Scope and Limits, Oxfoerd: Oxford University Press, 1979.

6 Basic of this science is definitely the Qur'an because it consists of a collection of basic theory (grand theory) that originated from it.

7 John Kemeny, A Philosopher looks at Science, (New York: Van Nostrand Reinhold, 1981), p. 175.

8 Sheldon, J.Lachman, The Foundations of Science, (New York: Vantage Press, a989), p. 13. 